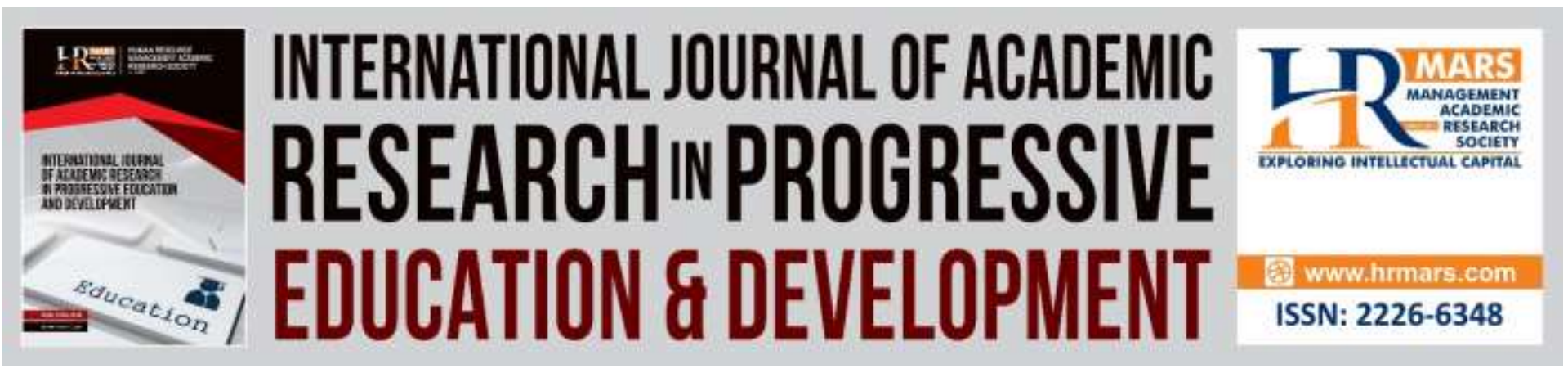

\title{
Exploring the 21 st Century Teaching and Learning Practice among Mathematics Secondary School Teachers
}

\section{Saliza Ali, Siti Mistima Maat}

To Link this Article: http://dx.doi.org/10.6007/IJARPED/v8-i2/5990

DOI: 10.6007/IJARPED/v8-i2/5990

Received: 12 April 2019, Revised: 22 May 2019, Accepted: 09 June 2019

Published Online: 19 July 2019

In-Text Citation: (Ali \& Maat, 2019)

To Cite this Article: Ali, S., \& Maat, S. M. (2019). Exploring the 21st Century Teaching and Learning Practice among Mathematics Secondary School Teachers. International Journal of Academic Research in Progressive Education and Development, 8(2), 361-378.

\section{Copyright: (C) 2019 The Author(s)}

Published by Human Resource Management Academic Research Society (www.hrmars.com)

This article is published under the Creative Commons Attribution (CC BY 4.0) license. Anyone may reproduce, distribute, translate and create derivative works of this article (for both commercial and non-commercial purposes), subject to full attribution to the original publication and authors. The full terms of this license may be seen

at: http://creativecommons.org/licences/by/4.0/legalcode

\section{Vol. 8(2) 2019, Pg. 361 - 378}

Full Terms \& Conditions of access and use can be found at http://hrmars.com/index.php/pages/detail/publication-ethics 


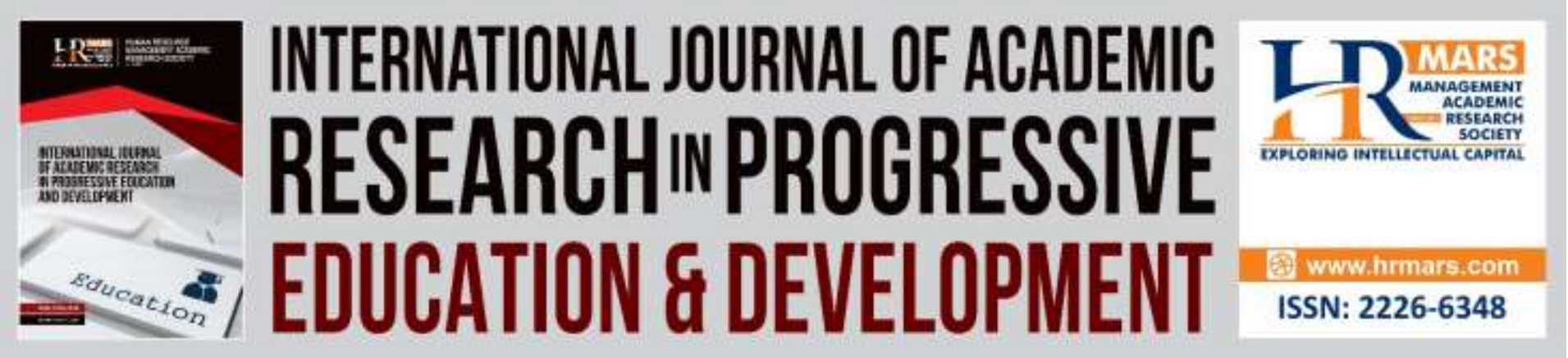

\title{
Exploring the 21 st Century Teaching and Learning Practice among Mathematics Secondary School Teachers
}

\author{
Saliza Ali, Siti Mistima Maat \\ Faculty of Education, Universiti Kebangsaan Malaysia \\ Email: salizaali2016@gmail.com, sitimistima@ukm.edu.my
}

\begin{abstract}
The reality nowadays, practicing teaching mathematics in the classroom needs efficient implementation. This research is conducted to cater this situation. The survey study is aimed to identify the practice stages in teaching and learning in 21st century, as well as high order thinking skills (HOTS) among mathematics teachers. This study involved 31 mathematics teachers pursuing master's degree at Universiti Kebangsaan Malaysia which were selected through simple random sampling. The questionnaires consist of teachers' demographics, 21st century teaching practice among mathematics teachers were used in the data collection process. Descriptive analysis consist of the value of frequency, percentage and mean which were also used in this study. The study found that the 21st century teaching and learning practice in general to be high. It has also been found that mathematics teacher applied problem-solving skills in teaching and learning but on the other side, they have deficiency in the usage of technological skills. Hence, technological skills of mathematics teachers need to be improved by providing them with courses for the teachers to attend or special programs related to technology usage in teaching and learning for them to follow. Hopefully with this study's findings, they can help the Ministry of Education to plan a strategize programs or courses that can increase the level of teaching and learning practice 21st century of teachers to improve the quality of Malaysia education especially in Mathematics subject.
\end{abstract}

Keywords: $21^{\text {st }}$ Century T\&L Practice, HOTS, Teachers' Content Knowledge

\section{Introduction}

Education is the main contributor to the development of social capital and the country's economy. Education also sparks creativity and generate innovation among younger generation to equip them with skills needed to compete in the job market. In addition, education helps in enabling the overall economic growth (Pelan Pembangunan Pendidikan Malaysia (PPPM) 2013-2025). $21^{\text {st }}$ century teaching and learning (T\&L) is an important element in the country's education system. This is in line with the rapid development of education. $21^{\text {st }}$ century T\&L is one of the aspirations of the Ministry of Education (MOE) Malaysia in the development of $21^{\text {st }}$ century skills that are relevant to 
the local context. Accordingly, providing a platform for Malaysians to compete internationally (Hisyam \& Nasruddin, 2016). Hence, the $21^{\text {st }}$ century T\&L is expected to produce critically thinking students and are expert in solving problems in everyday life.

Among the $21^{\text {st }}$ century learning goals is to produce students who are highly productive, proficient in communication, have high-order of thinking skills (HOTS) and skilful in the use of information and communication technology (ICT).This is in line with the Model Partner for $21^{\text {st }}$ Century Skill (2015). This model combines several components of students' success with the $21^{\text {st }}$ century support system such as critical thinking skills, communication skills, reflection skills, collaborative skills, assessment skills, problem-solving skills, technological skills, innovation skills and creativity. Critical thinking skills comprise of reasoning, being creative and responsible, solving problems, making judgements and decisions, accessing, evaluating, and using information and making decisions (Wilson-Ahlstrom, et al., 2014). The communication skills are the process of delivering and receiving information that may come in various forms - either verbal or non-verbal (Quieng et al., 2015). Reflection skills involve a process of teacher recalling their teaching, approach or strategy, and their self-ability in teaching. This level of skills is important as the teacher can detect various weakness or flaws during T\&L. Collaborative skills can be referred to the interpersonal skills, teamwork, flexibility and cultural competencies that require a lot of understanding, compromise, sacrifice and effort (Wilson-Ahlstrom, et al., 2014). Assessment skills encompass the process of obtaining information to identify the students' progress and achievement using various approaches and methods ).

Problem-solving skills are related to critical thinking skills, which can be a tool to trigger new ideas or abilities. Creativity is a form of information transfer which involves the use of knowledge or skills that were previously learned on new situations (Ormrod, 2014). Innovation is an improvement and modernization of the existing T\&L.

Teachers need to equip themselves with these skills before teaching effectively. This is because teachers are the factors that underpin success in building the $21^{\text {st }}$ century skills of the students. Teachers can also contribute to the students' weakness in mastering the communication skills, critical thinking and problem solving if they are not well-equipped with the $21^{\text {st }}$ century skills (Carlgren, 2013). In addition, teachers also the key role in keeping up with the progress of the education development. Teachers are required to understand and be willing to make changes in $T \& L$ to suit with the $21^{\text {st }}$ century learning. Thus, the teachers' $21^{\text {st }}$ century $T \& L$ practice is seen as an effort that should be taken seriously. This is also coherent with the aspirations of Ministry of Education (MOE) Malaysia that the teachers can identify the $21^{\text {st }}$ century skills that are relevant to the local context, providing a platform for Malaysians to compete internationally (Hisyam \& Nasruddin, 2016).

\section{Statement of the Problem}

This is a descriptive study which was implemented to identify the levels of mathematics teachers in their teaching and learning (T\&L) practices. Therefore, quantitative method of survey research design was used to collect the data. This method collects information from predetermined samples. This study used questionnaire to obtain information regarding to the respondents' background and mathematics 
teachers' $21^{\text {st }}$ century T\&L practices. The use of survey method using questionnaire is to easily facilitate researchers to obtain cooperation from the respondents. Besides, using questionnaire is easier to administer and the data is easily collected and analysed (McMillan \& Schumacher, 2014).

\section{Location, Population and Sample}

This study was conducted on mathematics teachers who are teaching in Besut district, Terengganu. A total of 226 teachers ( 80 males and 146 females) were selected to be the samples in this study. The respondents were selected based on teachers who taught Mathematics at the school which consists of 123 primary school teachers and 103 secondary school teachers. The data was collected for four months from November 2017 to February 2018 by distributing the questionnaires. The size of the sample is enough to carry out one's study. The minimum size for an inference is around 30 people (Fraenkel \& Wallen, 1993).

\section{Research Instrument}

This study used questionnaires on the $21^{\text {st }}$ century T\&L which were modified from Badrul Hisham and Nasaruddin's (2017) questionnaires. There are eight constructs in the $21^{\text {st }}$ century T\&L practices which are communication, reflection, collaborative, assessment, problem-solving, technological, and innovation skills as well as creativity. The reliability of this instrument is based on the value of Cronbach's Alpha which is 0.901 . This instrument uses 5 -points Likert scale that indicates $1=$ never, $2=$ almost never, 3 = rarely, $4=$ often and 5 = very often.

\section{Research Findings}

The findings of this study were analyzed and summarized based on the objectives and research questions. Descriptive analysis was used to describe the samples' demographic using frequency and percentages. The descriptive statistical analysis is based on the interpretation of the mean score. The mean score is as shown in Table 1 . This analysis was used to view the levels of the $21^{\text {st }}$ century T\&L practices. Table 2 shows the demographic mathematics teachers in terms of gender and schools.

Table 1: Mean Score

\begin{tabular}{ll}
\hline Mean score & Interpretation (level) \\
\hline $1.00-2.33$ & Low \\
$2.34-3.66$ & Moderate \\
$3.67-5.00$ & High \\
\hline
\end{tabular}

Sourcer: Pallant (2007)

Table 2: Demographic Analysis

\begin{tabular}{lll}
\hline Respondent & Frequency & Percentage (\%) \\
\hline Male & 80 & 35.4 \\
Female & 146 & 64.6 \\
Secondary School & 103 & 45.6 \\
Primary School & 123 & 54.4 \\
\hline
\end{tabular}


INTERNATIONAL JOURNAL OF ACADEMIC RESEARCH IN PROGRESSIVE EDUCATION AND DEVELOPMENT

Vol. 8, No. 2, 2019, E-ISSN: 2226-6348 C 2019 HRMARS

What are the levels of the 21st century T\&L practices among mathematics teachers in terms of communication, reflection, collaborative, assessment, problem-solving, technological, and innovation skills as well as creativity?

The Mathematics Teachers' Levels of $21^{\text {st }}$ Century Teaching and Learning Practice This section describes the results from the self-assessment of the $21^{\text {st }}$ century teaching and learning practice. Eight constructs as mentioned above are to be discussed in this study. Descriptive analysis using mean and standard deviation was done to determine the levels of $21^{\text {st }}$ century T\&L practice. The results are shown as follows.

Table 3: The Mathematics Teachers' Levels of $21^{\text {st }}$ Century T\&L Practice

\begin{tabular}{|c|c|c|c|}
\hline Scale & Mean & $\begin{array}{l}\text { Standar } \\
d \\
\text { Deviati } \\
\text { on }\end{array}$ & $\begin{array}{l}\text { Interpretati } \\
\text { on }\end{array}$ \\
\hline $\begin{array}{l}\text { Communicati } \\
\text { on Skills }\end{array}$ & 3.79 & 0.41 & High \\
\hline $\begin{array}{l}\text { Reflection } \\
\text { Skills }\end{array}$ & 3.73 & 0.37 & High \\
\hline $\begin{array}{l}\text { Collaborative } \\
\text { Skills }\end{array}$ & 3.62 & 0.45 & Moderate \\
\hline $\begin{array}{l}\text { Assessment } \\
\text { Skills }\end{array}$ & 3.77 & 0.33 & High \\
\hline $\begin{array}{l}\text { Problem- } \\
\text { solving Skills }\end{array}$ & 3.99 & 0.47 & High \\
\hline $\begin{array}{l}\text { Technologica } \\
\text { I Skills }\end{array}$ & 3.31 & 0.47 & Moderate \\
\hline Creativity & 3.76 & 0.43 & High \\
\hline $\begin{array}{l}\text { Innovation } \\
\text { Skills }\end{array}$ & 3.48 & 0.51 & Moderate \\
\hline Total Mean & 3.68 & 0.43 & High \\
\hline
\end{tabular}

The descriptive analysis in Table 3 shows that the 21st century T\&L practice among mathematics teachers for the problems-solving construct is at high level with mean $=3.99$ and $s d=0.47$. Meanwhile, the technological aspect is at the lowest with mean $=3.31$ and $s d=0.47$. Overall, the mean score of the 21 st century $T \& L$ practice of the mathematics teachers is at high level with mean $=3.68$ and $s d=0.43$. 
INTERNATIONAL JOURNAL OF ACADEMIC RESEARCH IN PROGRESSIVE EDUCATION AND DEVELOPMENT

Vol. 8, No. 2, 2019, E-ISSN: 2226-6348 C 2019 HRMARS

Table 4: The Mathematics Teachers' Levels of 21st Century T\&L

Practice in the Communication Skill Aspect

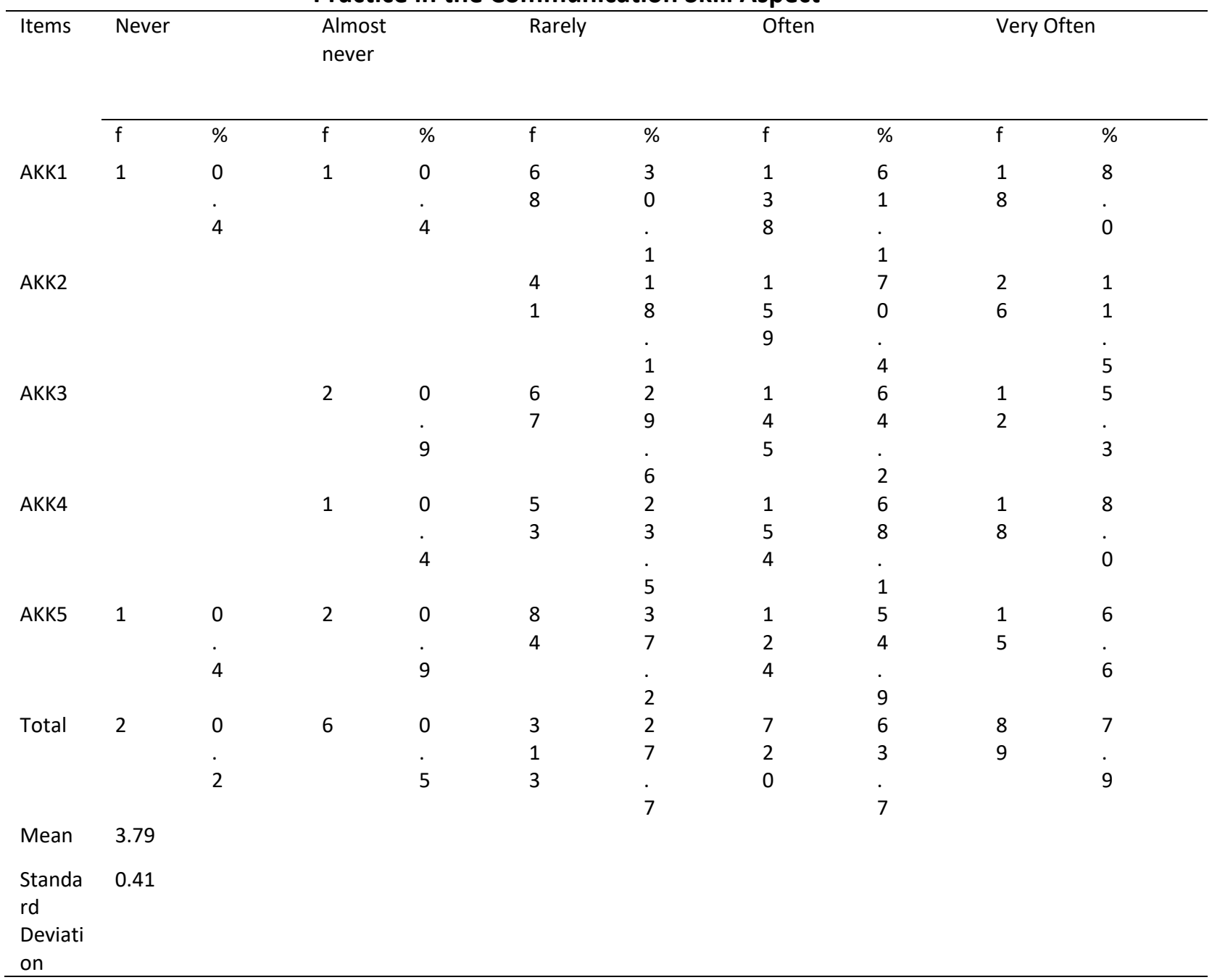

The overall descriptive analysis in Table 4 for communication skills aspect in the teachers' practice is at high level with $\min =3.79$ and $s d=0.41$. The overall frequency distribution and percentage show that teachers often practised communication skills during T\&L sessions as the percentage of the scale 'often' and 'very often' have the highest percentage of $71.6 \%$. All of these items show a percentage that is greater than $60 \%$ for the 'often' and 'very often' scales. Item AKK2, "Encouraging students to communicate in carrying out group work provided by the teachers" has the highest percentage of $81.9 \%$. This result shows that teachers have always encouraged their students to communicate while performing tasks in groups. However, the teachers did not emphasize more on the practice of giving group assignments to the students as the item AKK1, "Giving the group assignment to the students" has the lowest percentage of $66.1 \%$. 
INTERNATIONAL JOURNAL OF ACADEMIC RESEARCH IN PROGRESSIVE EDUCATION AND DEVELOPMENT

Vol. 8, No. 2, 2019, E-ISSN: 2226-6348 C 2019 HRMARS

Table 5: The Mathematics Teachers' Levels of 21st Century T\&L

Practice in the Reflection Skills Aspect

\begin{tabular}{|c|c|c|c|c|c|c|c|c|c|c|}
\hline \multirow[t]{2}{*}{ Items } & \multicolumn{2}{|c|}{ Never } & \multicolumn{2}{|c|}{$\begin{array}{l}\text { Almost } \\
\text { never }\end{array}$} & \multicolumn{2}{|c|}{ Rarely } & \multicolumn{2}{|c|}{ Often } & \multicolumn{2}{|c|}{ Very Often } \\
\hline & $f$ & $\%$ & $f$ & $\%$ & $f$ & $\%$ & $f$ & $\%$ & $f$ & $\%$ \\
\hline \multirow[t]{4}{*}{ AKR1 } & & & 2 & 0 & 7 & 3 & 1 & 6 & 7 & 3 \\
\hline & & & & . & 6 & 3 & 4 & 2 & & . \\
\hline & & & & 9 & & . & 1 & . & & 1 \\
\hline & & & & & & 6 & & 4 & & \\
\hline \multirow[t]{4}{*}{ AKR2 } & & & 4 & 1 & 9 & 4 & 1 & 5 & 6 & 2 \\
\hline & & & & . & 9 & 3 & 1 & 1 & & . \\
\hline & & & & 8 & & . & 7 & . & & 7 \\
\hline & & & & & & 8 & & 8 & & \\
\hline \multirow[t]{4}{*}{ AKR3 } & 1 & 0 & 3 & 1 & 1 & 4 & 1 & 4 & 7 & 3 \\
\hline & & . & & . & 1 & 8 & 0 & 6 & & . \\
\hline & & 4 & & 3 & 0 & . & 5 & . & & 1 \\
\hline & & & & & & 7 & & 5 & & \\
\hline \multirow[t]{4}{*}{ AKR4 } & & & & & 2 & 1 & 1 & 5 & 7 & 3 \\
\hline & & & & & 4 & 0 & 3 & 8 & 0 & 1 \\
\hline & & & & & & . & 2 & . & & . \\
\hline & & & & & & 6 & & 4 & & 0 \\
\hline \multirow[t]{4}{*}{ Total } & 1 & 0 & 9 & 1 & 3 & 3 & 4 & 5 & 9 & 1 \\
\hline & & . & & . & 0 & 4 & 9 & 4 & 0 & 0 \\
\hline & & 4 & & 0 & 9 & . & 5 & . & & . \\
\hline & & & & & & 2 & & 8 & & 0 \\
\hline Mean & 3.73 & & & & & & & & & \\
\hline Standarc & 0.36 & & & & & & & & & \\
\hline Deviatio & & & & & & & & & & \\
\hline
\end{tabular}

Table 5 shows the descriptive analysis of reflection skills and the total mean is at high level with mean $=3.73$ and $s d=0.36$. Overall, the teachers have often practised the above mentioned skills in T\&L sessions as the percentage of 'very often' scale is the highest which is $64.8 \%$ compared to other scales. However, there are also items that obtained percentage less than $50 \%$ for the 'often' and 'very often' scales. This is because the items indicated as being less practised compared to other items. The item that has the highest percentage of $89.4 \%$ is item AKR4, "Writing a reflection aster T\&L session" while item AKR3, "Getting feedbacks from peers after T\&L session" has the lowest percentage of $49.6 \%$. Thus, teachers have always performed reflection themselves after T\&L sessions but did not emphasize optimally on getting feedbacks from their colleagues. 
INTERNATIONAL JOURNAL OF ACADEMIC RESEARCH IN PROGRESSIVE EDUCATION AND DEVELOPMENT

Vol. 8, No. 2, 2019, E-ISSN: $2226-6348$ @ 2019 HRMARS

Table 6: The Mathematics Teachers' Levels of 21st Century T\&L

Practice in the Collaborative Skills Aspect

\begin{tabular}{|c|c|c|c|c|c|c|c|c|c|c|}
\hline \multirow[t]{2}{*}{ Items } & \multicolumn{2}{|c|}{ Never } & \multicolumn{2}{|c|}{ Almost never } & \multicolumn{2}{|c|}{ Rarely } & \multicolumn{2}{|c|}{ Often } & \multicolumn{2}{|c|}{ Very Often } \\
\hline & $f$ & $\%$ & $f$ & $\%$ & $f$ & $\%$ & $f$ & $\%$ & $f$ & $\%$ \\
\hline $\begin{array}{l}\text { AKKO } \\
1\end{array}$ & & & 6 & $\begin{array}{l}2 \\
7\end{array}$ & $\begin{array}{l}9 \\
2\end{array}$ & $\begin{array}{l}4 \\
0 \\
. \\
7\end{array}$ & $\begin{array}{l}1 \\
0 \\
9\end{array}$ & $\begin{array}{l}4 \\
8 \\
2 \\
2\end{array}$ & $\begin{array}{l}1 \\
9\end{array}$ & $\begin{array}{l}8 \\
4 \\
4\end{array}$ \\
\hline $\begin{array}{l}\text { AKKO } \\
2\end{array}$ & & & 8 & $\begin{array}{l}3 \\
5 \\
5\end{array}$ & $\begin{array}{l}1 \\
0 \\
8\end{array}$ & $\begin{array}{l}4 \\
7 \\
8 \\
8\end{array}$ & $\begin{array}{l}9 \\
6\end{array}$ & $\begin{array}{l}4 \\
2 \\
5 \\
5\end{array}$ & $\begin{array}{l}1 \\
4\end{array}$ & $\begin{array}{l}6 \\
2 \\
2\end{array}$ \\
\hline $\begin{array}{l}\text { AKKO } \\
3\end{array}$ & & & 5 & $\begin{array}{l}2 \\
2\end{array}$ & $\begin{array}{l}8 \\
3\end{array}$ & $\begin{array}{l}3 \\
6 \\
7 \\
7\end{array}$ & $\begin{array}{l}1 \\
2 \\
9\end{array}$ & $\begin{array}{l}5 \\
7 \\
. \\
1\end{array}$ & 9 & $\begin{array}{l}4 \\
\dot{0}\end{array}$ \\
\hline $\begin{array}{l}\text { AKKO } \\
4\end{array}$ & & & 3 & $\begin{array}{l}1 \\
3\end{array}$ & $\begin{array}{l}7 \\
3\end{array}$ & $\begin{array}{l}3 \\
2 \\
3 \\
3\end{array}$ & $\begin{array}{l}1 \\
4 \\
0\end{array}$ & $\begin{array}{l}6 \\
1 \\
9 \\
9\end{array}$ & $\begin{array}{l}1 \\
0\end{array}$ & $\begin{array}{l}4 \\
4\end{array}$ \\
\hline Total & & & $\begin{array}{l}2 \\
2\end{array}$ & $\begin{array}{l}2 \\
4\end{array}$ & $\begin{array}{l}3 \\
5 \\
6\end{array}$ & $\begin{array}{l}3 \\
9 \\
4\end{array}$ & $\begin{array}{l}4 \\
7 \\
4\end{array}$ & $\begin{array}{l}5 \\
2 \\
4\end{array}$ & $\begin{array}{l}5 \\
2\end{array}$ & $\begin{array}{l}5 \\
8\end{array}$ \\
\hline Mean & \multicolumn{10}{|c|}{3.62} \\
\hline $\begin{array}{l}\text { Stand } \\
\text { ard } \\
\text { Deviat } \\
\text { ion }\end{array}$ & 0.4 & & & & & & & & & \\
\hline
\end{tabular}

The total mean from the collaborative skills aspect is 3.62 with $s d=0.45$ as illustrated in Table 6. Overall, the 'often' scale is the scale that obtain the highest frequency percentage of $52.4 \%$ as compared to other scales. Hence, the teachers were found to have often implemented the collaborative skills in their T\&L practices even though the percentage is not that high. The item that has the highest percentage of $66.3 \%$ is item AKKO4, "Using collaborative approach" whereas item AKKO2, "Encouraging the

Table 7: The Mathematics Teachers' Levels of 21st Century T\&L

Practice in the Assessment Skills Aspect

\begin{tabular}{|c|c|c|c|c|c|c|c|c|c|c|}
\hline \multirow[t]{2}{*}{ Items } & \multicolumn{2}{|c|}{ Never } & \multicolumn{2}{|c|}{$\begin{array}{l}\text { Almost } \\
\text { never }\end{array}$} & \multicolumn{2}{|c|}{ Rarely } & \multicolumn{2}{|c|}{ Often } & \multicolumn{2}{|c|}{$\begin{array}{l}\text { Very } \\
\text { Often }\end{array}$} \\
\hline & $f$ & $\%$ & $f$ & $\%$ & $f$ & $\%$ & $f$ & $\%$ & $f$ & $\%$ \\
\hline AKP1 & & & & & $\begin{array}{l}4 \\
1\end{array}$ & $\begin{array}{l}1 \\
8 \\
1 \\
1\end{array}$ & $\begin{array}{l}1 \\
5 \\
7\end{array}$ & $\begin{array}{l}6 \\
9 \\
5 \\
5\end{array}$ & $\begin{array}{l}2 \\
8\end{array}$ & $\begin{array}{l}1 \\
2 \\
4 \\
4\end{array}$ \\
\hline
\end{tabular}


INTERNATIONAL JOURNAL OF ACADEMIC RESEARCH IN PROGRESSIVE EDUCATION AND DEVELOPMENT

Vol. 8, No. 2, 2019, E-ISSN: 2226-6348 ㄷ 2019 HRMARS

\begin{tabular}{|c|c|c|c|c|c|c|c|c|c|}
\hline AKP2 & & 1 & 4 & $\begin{array}{l}1 \\
0 \\
5\end{array}$ & $\begin{array}{l}4 \\
6 \\
5 \\
5\end{array}$ & $\begin{array}{l}1 \\
1 \\
7\end{array}$ & $\begin{array}{l}5 \\
1 \\
. \\
8\end{array}$ & 3 & $\begin{array}{l}1 \\
3\end{array}$ \\
\hline AKP3 & & 2 & $\begin{array}{l}0 \\
\dot{9}\end{array}$ & $\begin{array}{l}8 \\
8\end{array}$ & $\begin{array}{l}3 \\
8 \\
. \\
9\end{array}$ & $\begin{array}{l}1 \\
3 \\
4\end{array}$ & $\begin{array}{l}5 \\
9 \\
5 \\
3\end{array}$ & 2 & $\begin{array}{l}0 \\
9\end{array}$ \\
\hline AKP4 & & 6 & $\begin{array}{l}2 \\
7\end{array}$ & $\begin{array}{l}1 \\
0 \\
9\end{array}$ & $\begin{array}{l}4 \\
8 \\
. \\
2\end{array}$ & $\begin{array}{l}1 \\
0 \\
4\end{array}$ & $\begin{array}{l}4 \\
6 \\
. \\
0\end{array}$ & 7 & $\begin{array}{l}3 \\
1 \\
1\end{array}$ \\
\hline AKP5 & & & & $\begin{array}{l}3 \\
1\end{array}$ & $\begin{array}{l}1 \\
3 \\
. \\
7\end{array}$ & $\begin{array}{l}1 \\
7 \\
1\end{array}$ & $\begin{array}{l}7 \\
5 \\
7\end{array}$ & $\begin{array}{l}2 \\
4\end{array}$ & $\begin{array}{l}1 \\
0 \\
6\end{array}$ \\
\hline AKP6 & & & & $\begin{array}{l}2 \\
6\end{array}$ & $\begin{array}{l}1 \\
1 \\
5 \\
5\end{array}$ & $\begin{array}{l}1 \\
5 \\
6\end{array}$ & $\begin{array}{l}6 \\
9 \\
. \\
0\end{array}$ & $\begin{array}{l}4 \\
4\end{array}$ & $\begin{array}{l}1 \\
9 \\
5\end{array}$ \\
\hline Total & & 9 & $\begin{array}{l}0 \\
7 \\
7\end{array}$ & $\begin{array}{l}4 \\
0 \\
0\end{array}$ & $\begin{array}{l}2 \\
9 \\
. \\
5\end{array}$ & $\begin{array}{l}8 \\
3 \\
9\end{array}$ & $\begin{array}{l}6 \\
1 \\
. \\
9\end{array}$ & $\begin{array}{l}1 \\
0 \\
8\end{array}$ & $\begin{array}{l}8 \\
. \\
0\end{array}$ \\
\hline Mean & 3.77 & & & & & & & & \\
\hline $\begin{array}{l}\text { Stand } \\
\text { ard } \\
\text { Devia } \\
\text { tion }\end{array}$ & 0.33 & & & & & & & & \\
\hline
\end{tabular}

The descriptive analysis in Table 7 displays that the total mean for the assessment skills aspect is at high level with mean $=3.77$ and $s d=0.36$. The total percentage for the 'often' and 'very often' scales is $69.2 \%$. Therefore, it is the highest percentage compared to other scales. From this finding, it shows that teachers have regularly practised assessment skills during their T\&L session. Item AKP6, "Give immediate feedback on the students' assignments" obtains $87.6 \%$ which is the highest frequency percentage while item AKP4, "Encouraging the students' to assess their peers" has the lowest frequency percentage of $47.8 \%$. This situation summaries that the teachers have always given their feedbacks on the students' work as soon as possible but the students were likely to have less motivation to evaluate their own peers. These happened due to various factors such as the teachers believed that students' abilities were influenced by the insufficient and time constraint. 
INTERNATIONAL JOURNAL OF ACADEMIC RESEARCH IN PROGRESSIVE EDUCATION AND DEVELOPMENT

Vol. 8, No. 2, 2019, E-ISSN: 2226-6348 C 2019 HRMARS

Table 8: The Mathematics Teachers' Levels of 21st Century T\&L Practice from Problem-solving Skills Aspect

\begin{tabular}{|c|c|c|c|c|c|c|c|c|c|c|}
\hline \multirow[t]{2}{*}{ Items } & \multicolumn{2}{|l|}{$\begin{array}{l}\mathrm{Ne} \\
\text { ve } \\
r\end{array}$} & \multicolumn{2}{|c|}{$\begin{array}{l}\text { Al } \\
\text { mo } \\
\text { st } \\
\text { ne } \\
\text { ver }\end{array}$} & \multicolumn{2}{|c|}{$\begin{array}{l}\text { Rarel } \\
\text { y }\end{array}$} & \multicolumn{2}{|c|}{$\begin{array}{l}\text { Ofte } \\
n\end{array}$} & \multicolumn{2}{|c|}{$\begin{array}{l}\text { Very } \\
\text { Ofte } \\
n\end{array}$} \\
\hline & $f$ & $\%$ & $f$ & $\%$ & $f$ & $\%$ & $f$ & $\%$ & $f$ & $\%$ \\
\hline \multirow[t]{4}{*}{ APM1 } & & & & & 3 & 1 & 1 & 7 & 3 & 1 \\
\hline & & & & & 2 & 4 & 6 & 1 & 2 & 4 \\
\hline & & & & & & . & 2 & . & & . \\
\hline & & & & & & 2 & & 7 & & 2 \\
\hline \multirow[t]{4}{*}{ APM2 } & & & & & 3 & 1 & 1 & 5 & 6 & 2 \\
\hline & & & & & 3 & 4 & 3 & 8 & 1 & 7 \\
\hline & & & & & & . & 2 & . & & . \\
\hline & & & & & & 6 & & 4 & & 0 \\
\hline \multirow[t]{4}{*}{ APM3 } & & & 1 & 0 & 2 & 1 & 1 & 7 & 3 & 1 \\
\hline & & & & . & 9 & 2 & 6 & 2 & 2 & 4 \\
\hline & & & & 4 & & . & 4 & . & & . \\
\hline & & & & & & 8 & & 6 & & 2 \\
\hline \multirow[t]{4}{*}{ APM4 } & & & 2 & 0 & 5 & 2 & 1 & 6 & 2 & 1 \\
\hline & & & & . & 9 & 6 & 3 & 1 & 7 & 1 \\
\hline & & & & 9 & & . & 8 & . & & . \\
\hline & & & & & & 1 & & 1 & & 9 \\
\hline \multirow[t]{4}{*}{ Total } & & & 3 & 0 & 1 & 1 & 5 & 6 & 1 & 1 \\
\hline & & & & . & 5 & 6 & 9 & 5 & 5 & 6 \\
\hline & & & & 3 & 3 & . & 6 & . & 2 & . \\
\hline & & & & & & 9 & & 9 & & 8 \\
\hline Mean & 3.99 & & & & & & & & & \\
\hline Standard & 0.47 & & & & & & & & & \\
\hline Deviation & & & & & & & & & & \\
\hline
\end{tabular}

The descriptive analysis in Table 8 portrays the total mean for the problem-solving skills aspect is at high level with mean $=3.99$ and $s d=0.47$. Overall, the 'often' scale has the highest percentage of $65.9 \%$ indicating that teachers have habitually practised the problem-solving skills in their T\&L session. The item that has the highest percentage of frequency is APM3, "Encouraging the students to use various problem-solving strategies" which is $86.6 \%$ whereas item APM4, "Ensuring the given problems are multidisciplinary" has the lowest frequency percentage of $73 \%$. To conclude, teachers were found to have always encouraged the students to diversify their strategies to solve problems but the problems given by the teachers were not multidisciplinary 
INTERNATIONAL JOURNAL OF ACADEMIC RESEARCH IN PROGRESSIVE EDUCATION AND DEVELOPMENT

Vol. 8, No. 2, 2019, E-ISSN: 2226-6348 @ 2019 HRMARS

Table 9: The Mathematics Teachers' Levels of 21st Century T\&L Practice in the Technological Skills Aspect

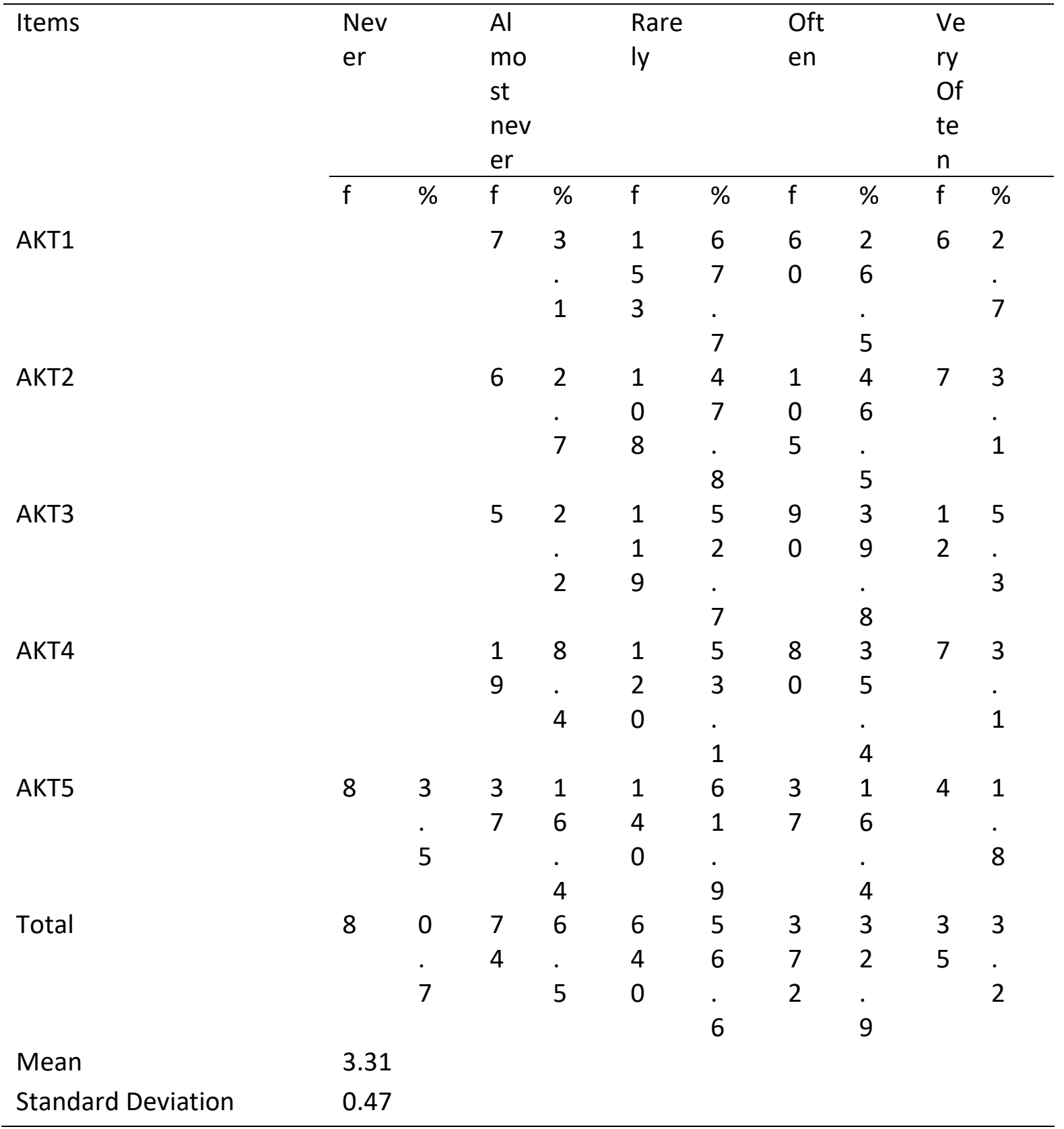

Table 9 shows the descriptive analysis for technological skills aspect. The total mean of the technological skills is at moderate level with mean $=3.31$ and $s d=0.47$. The 'rarely' scale has the highest percentage of $54.9 \%$ which indicates that the teachers have rarely used technological skills in their T\&L sessions. However, the teachers still encouraged their students to use suitable technology in finishing their assignments. This is based on the result of item AKT2, "Encouraging students to use technology in completing their tasks" has the highest percentage which is $50 \%$. Meanwhile, item AKT5, "Using online 
INTERNATIONAL JOURNAL OF ACADEMIC RESEARCH IN PROGRESSIVE EDUCATION AND DEVELOPMENT

Vol. 8, No. 2, 2019, E-ISSN: $2226-6348$ @ 2019 HRMARS

learning such as e-book, e-video, e-learning, and others" has the lowest percentage of frequency which is $17.3 \%$. Hence, the use of online learning was still low in the teachers' T\&L practice.

Table 10: The Mathematics Teachers' Levels of 21st Century T\&L Practice in the Creativity Aspect

\begin{tabular}{|c|c|c|c|c|c|c|c|c|c|c|}
\hline \multirow[t]{2}{*}{ Items } & \multicolumn{2}{|l|}{ Never } & \multicolumn{2}{|c|}{$\begin{array}{l}\text { Almost } \\
\text { never }\end{array}$} & \multicolumn{2}{|c|}{ Rarely } & \multicolumn{2}{|c|}{ Often } & \multicolumn{2}{|c|}{$\begin{array}{l}\text { Very } \\
\text { Often }\end{array}$} \\
\hline & $f$ & $\%$ & $f$ & $\%$ & $f$ & $\%$ & $f$ & $\%$ & $f$ & $\%$ \\
\hline \multirow[t]{4}{*}{ AK1 } & & & 1 & 0 & 5 & 2 & 1 & 6 & 1 & 4 \\
\hline & & & & . & 7 & 5 & 5 & 9 & 0 & . \\
\hline & & & & 4 & & . & 8 & . & & 4 \\
\hline & & & & & & 2 & & 9 & & \\
\hline \multirow[t]{4}{*}{ AK2 } & & & 1 & 0 & 6 & 2 & 1 & 6 & 1 & 4 \\
\hline & & & & . & 0 & 6 & 5 & 8 & 1 & $\cdot$ \\
\hline & & & & 4 & & . & 4 & . & & 9 \\
\hline & & & & & & 5 & & 1 & & \\
\hline \multirow[t]{4}{*}{ AK3 } & & & & & 7 & 3 & 1 & 6 & 8 & 3 \\
\hline & & & & & 7 & 4 & 4 & 2 & & . \\
\hline & & & & & & . & 1 & . & & 5 \\
\hline & & & & & & 1 & & 4 & & \\
\hline \multirow[t]{4}{*}{ AK4 } & & & 1 & 0 & 5 & 2 & 1 & 6 & 1 & 5 \\
\hline & & & & . & 9 & 6 & 5 & 7 & 3 & 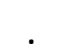 \\
\hline & & & & 4 & & . & 3 & . & & 8 \\
\hline & & & & & & 1 & & 7 & & \\
\hline \multirow[t]{4}{*}{ Total } & & & 3 & 0 & 2 & 2 & 6 & 6 & 4 & 4 \\
\hline & & & & . & 5 & 8 & 0 & 7 & 2 & \\
\hline & & & & 3 & 3 & . & 6 & . & & 6 \\
\hline & & & & & & 0 & & 0 & & \\
\hline Mean & 3.76 & & & & & & & & & \\
\hline Stand & 0.43 & & & & & & & & & \\
\hline $\begin{array}{l}\text { ard } \\
\text { Deviat }\end{array}$ & & & & & & & & & & \\
\hline ion & & & & & & & & & & \\
\hline
\end{tabular}

The descriptive analysis in Table 10 shows that the total mean of creativity skill is at a high level with mean $=3.76$ and $s d=0.43$. Overall, the 'often' scale obtains the highest percentage of $66.6 \%$ and indicates that the teachers often practice creativity during their T\&L session. Item AK1, "Using creativity in T\&L" has the highest percentage of frequency which is 74.45 while item AK3, "Applying the creativity elements during T\&L process" has the lowest percentage of frequency which is $65.9 \%$. Hence, teachers have often applied creativity skills during T\&L sessions but the creativity element was still not implemented during T\&L process. 
Table 11: The Mathematics Teachers' Level of 21st Century T\&L Practice from Innovation Skill Aspect

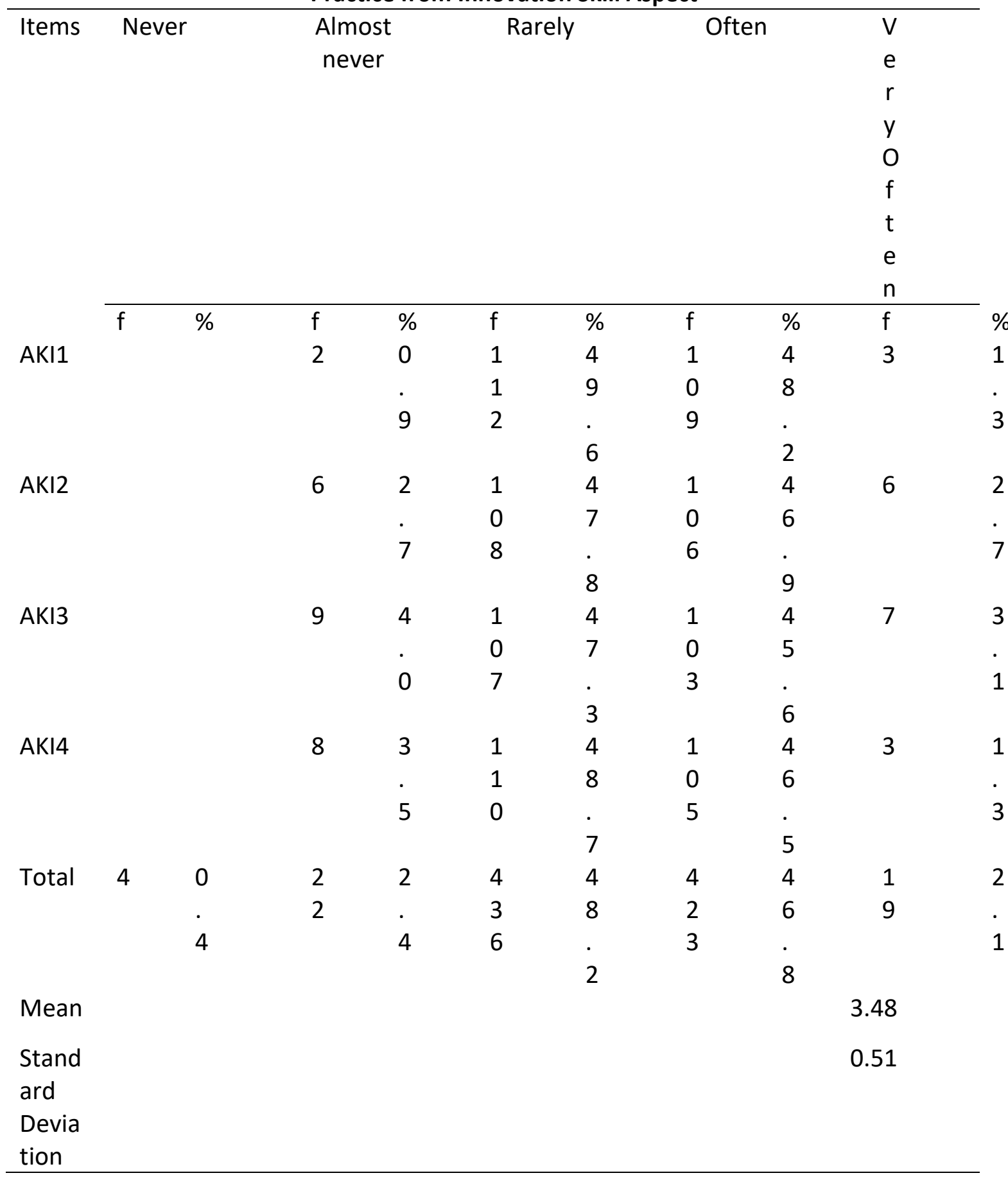

The descriptive analysis in Table 11 illustrates the overall mean of innovation skills as at moderate level with mean $=3.48$ and $s d=0.51$. The 'rarely' scale has the highest percentage of $48.2 \%$ which indicates that teachers have rarely implemented innovation skills in their T\&L practices. The item that obtained the highest percentage of $49.6 \%$ is item AKI2, "Delivering innovative inputs in the classroom" whereas 
item AKI4, "Applying innovative skills in a students' group work" has the lowest percentage of frequency of $47.8 \%$. These findings suggest that although the teachers did not put a lot of work in implementing the innovative skills, but the teachers were still trying to give innovative inputs in the classroom.

\section{Discussion}

\section{The Mathematics Teachers' Level of $21^{\text {st }}$ Century Teaching and Learning Practice}

Based on the findings of this study, the mathematics teachers' level in practising the $21^{\text {st }}$ century teaching and learning (T\&L) is high and consistent with the study done by Amiree (2016) and Hisham and Nasruddin (2016). However, it is not in line with Uche et al. (2016) that found that there was moderate level in the teachers' awareness regarding to the $21^{\text {st }}$ century teaching and learning. Nevertheless, if every construct is examined, there are still many things that need to be done so that the $21^{\text {st }}$ century $T \& L$ will improve. For communication skills construct, it shows that the teachers have often encouraged their students to communicate in carrying out the group work given. This practice is very good because teachers with good communication skills can develop a fun and exciting learning environment (Nurul \& Isha, 2014), but the teachers were less likely to give assignments that involve group work to encourage the students to communicate. This indirectly reduces the students' communication skills in doing their tasks. The students have many ideas that can be developed and shared with friends during the learning process (Ahmad Rizal, 2016). Effective communication skills also refer to the communication that occurred among the students themselves during the group works and presentations. Therefore, teachers need to perform more activities that can enhance the students' communication skills (Ong Sze Chong, 2018). This is very significant because communication skills are considered as an important element that the students need to master. This element is vital to meet their needs during the $T \& L$ process as well as preparations to cope with working environment (Berry, 2012) or social interaction (Salmi \& Isha, 2014).

The results of this study also showed that the teachers have always performed reflection after T\&L sessions. In Ainon (2016) study on the T\&L session conducted by Arabic language teachers, it found the same insights as this study. Reflection skills can help the teachers identify their weaknesses and flaws during the T\&L process (Ainon, 2016). Indirectly, this practice can increase the quality of the teachers' work (Rosnah, Faizal \& Saedah, 2014). Therefore, reflection skills should always be practiced. On the other hand, teachers who always practise reflection skills, they still lack of skills that involve obtaining feedbacks from their colleagues after the T\&L sessions. This is due to the teachers who have put more effort on emphasizing the students' ability to master mathematics rather than getting feedbacks from their colleagues. Teachers need to get feedbacks from their colleagues more often to increase and improve the T\&L quality. This immediate action will increase their ability (Fatemeh, 2015) and give better impacts to their students in empowering mathematics. The findings of this study also indicates that the teachers have practised collaborative approach in T\&L sessions but less encouraged their students to use various types of social media to interact. Many factors can be the cause for this situation, as such there are limited number of media facilities that the teachers can use. Teachers may also be in a lack of control over such media applications such as Frog VLE, Telegram and others.

The results also showed that the teachers did not diversify the use of social media for students to interact. Thus, this illustrates that teachers are still bound by the usual use of social media without 
knowing that there are ways to diversify their usage. Assessment skills are the skills that must be implemented by teachers in line with the School-Based Assessment (PBS) system. Therefore, the skills have become the current practice for teachers. Nevertheless, these findings found that the encouragement for the students to assess their peers are relatively weak. Perhaps, this is because either the teachers were less likely to believe their students' ability to assess their peers or there were some time constraints during the T\&L sessions. Thus, in order to solve this issue, teachers need to put their trust in the students by giving them encouragement to assess their friends and allocate appropriate time for this practice.

This study has also found that the teachers have always stimulated their students to diversify their problem-solving strategies and applied problem-solving skills in their T\&L sessions in order for the students to be able to analyze a situation systematically and generate, implement, and evaluate any solution. There is no exception for the problem-solving skills in mathematics subject (Bruun, 2013). These skills are really important to stimulate the students' thinking. Students will not bound by only one problem-solving method. However, the findings also indicated that teachers gave less multidisciplinary type of solving problem and which was not consistent with the study by Arikan (2016). This may be because the teachers often focused on only one type of problem-solving method and this finding is similar with the study by Bruun (2013). Teachers must give variety of disciplines in problem-solving process so that the students are not bound to only one method (Bruun, 2013). The use of special modules can help teachers to improve their problem-solving skills (Takahashi, 2016). Teachers' technological skills are found to be at moderate level. This may be due to the teachers' skills level and the use of technology was still low (Amiree, 2016, Rizal \& Rehan, 2010) and teachers were still not wellprepared in using the latest technology in the T\&L process. However, it does not coincide with the findings of Sharifah and Kamarul (2011) which stated that teachers are prepared to use the ICT approaches. Overall, the use of technological skills is still low. Teachers were found to have always encouraged their students to use technology while doing assignments but the teachers used less online learning platform such as e-books, e-learning and others. This is because of the inadequate facilities at the school due to the various obstacles in applying the new approaches to the teachers' teaching (Anderson \& Piazza, 1996). These technological skills are closely related to the various facilities and the teachers' knowledge in using such equipment or software.

In this study, teachers were found to frequently add creativity in their T\&L practices. Amiree (2016) found that teachers a have high level of creativity which is consistent in this study's findings. Teachers' practice will affect the students' creativity indirectly (Noziati, 2017). Through creative T\&L activities, students can generate more fun learning experiences thus, able build new experiences in facing real life (Farhana, Hayati \& Nasir, 2015). However, the study found that teachers did not apply creative element in their T\&L process. The application of creative element requires teachers to make early preparations and increase their level of knowledge, so more time and willpower needed to ensure the success of this implementation. Meanwhile, the level of innovation skills for the $21^{\text {st }}$ century T\&L practice of mathematics teachers is found to be moderate. Teachers were found to be practicing less than $50 \%$ innovation skills in classroom. Innovation inputs were more emphasized compared to other skills in innovation skills such as using innovation skills in T\&L and applying element of innovation in T\&L process. 
Applying innovation skills in students' group work marked as the lowest level in this skills. This may be due to the lack of teachers' understanding or the skills themselves. This calls for the need for the teachers to work on the innovative skills thus, these skills can be applied in the T\&L successfully (Azman, 2018). Teachers who get sufficient training in innovative skills can increase the use of these skills in the classroom (Sanchez et al, 2012). Innovation skills are really important as they can give the students freedom and motivation in their learning process. As a result, they can invent new knowledge, solve problems, generate ideas and make wise decisions to face life challenges (Zamri, 2012). This is equivalent to the efforts of Ministry of Education to uplift the teaching profession by emphasizing on teamwork, pro-activity, creativity and innovation as well as producing generations who are capable of competing and facing challenges in this global world. Generally, many studies have found that teachers have been practicing the $21^{\text {st }}$ century $T \& L$ but the level of this practice needs to be further enhanced by mastering the skills of the $21^{\text {st }}$ century T\&L.

\section{Conclusion}

The major finding indicates that in this study teachers have profound level in practising the $21^{\text {st }}$ century $T \& L$ which can be shown by the quantitative data. However, certain element in the major construct including communication skill has to be improved. The usage of social media is rather limited among teachers due to moderate level of their technical skills. All these suggest a proactive action in ensuring the effectiveness of the integration of $21^{\text {st }}$ century T\& $L$ in classroom. Teachers professional development has to be upgraded through attending related programs, offered by the ministry of education. Teachers' community can also play role particularly in sharing experiences and ideas of their successful stories in classroom. Since reflection in this study is considered limited, then by instilling the importance of doing reflection of their T \& L practice will benefit them in improving the said skills.

In addition, mathematics teachers need to be well-equipped with the $21^{\text {st }}$ century T\&L skills to be able to compete and deal with increasingly challenging era of globalization. This study is expected to contribute significantly to various parties involved which are responsible in order to improve this country's education system especially in mathematics education. This study is also to meet the needs of the Malaysia Education Blueprint (2013-2025) under the system aspirations to increase the students' success so that it is aligned with the resources channelled into the system. Such studies should be continuously carried out as an improvement to the existing researches and provide additional values in order to produce the best teaching practice. Teachers also will be more at ease gain more satisfaction in carrying out their T\&L activities.

Therefore, the $21^{\text {st }}$ century T\&L practice study is expected to help in ensuring the achievement of nation education vision which will produce effective, efficient and caring mathematics teachers for the betterment of our education system. For future works, it is recommended to apply qualitative approach in exploring on what is actually happen in mathematics classroom?

\section{Acknowledgment}

This research was funded by the grant of GG-2018-011 which was awarded by Faculty of Education, Universiti Kebangsaan Malaysia. 
INTERNATIONAL JOURNAL OF ACADEMIC RESEARCH IN PROGRESSIVE EDUCATION AND

DEVELOPMENT

Vol. 8, No. 2, 2019, E-ISSN: 2226-6348 @ 2019 HRMARS

\section{References}

Md Rais, A. R. (2016). Dorongan dan kompetensi teknologi maklumat dan komunikasi (TMK) terhadap aplikasi pengajaran dalam kalangan guru di sekolah berasrama penuh. (Unpublished master thesis). Universiti Kebangsaan Malaysia, Selangor, Malaysia.

Ainon, W. (2016). Pengetahuan pedagogi isi kandungan guru Bahasa Arab sekolah rendah. (Unpublished doctoral thesis). Universiti Kebangsaan Malaysia, Selangor, Malaysia.

Al-Shehri, K. A. (2012). The influence of mathematics teachers' knowledge in technology, pedagogy and content (TPACK) on their teaching effectiveness in Saudi public schools. (Unpublished doctoral thesis). University of Kansas, Kansas, USA.

Ariffin, A. (2016). Kemahiran dan penggunaan elemen kemahiran abad ke-21 dalam kalangan guru sekolah menengah kebangsaan di daerah Kuala Selangor. (Unpublished master thesis). Universiti Kebangsaan Malaysia, Selangor, Malaysia.

Anderson, D. S. \& Piazza, J. A. (1996). Teaching and learning Mathematics in Constructivist Pre service Classrooms. Action In Teacher Education, 18(2), 51-62.

Arikan, E. E. (2016). Prospective teachers' beliefs about problem solving in multiple ways. Universal Journal of Educational Research, 4(7), 1727-1733.

https://doi.org/10.13189/ujer.2016.040727

Asma, A., Fatima, A., Sara, A. \& Suad, A. (2017).21st Century Professional Skill Training Programs for Faculty Members-A Comparative Study between Virginia Tec University, American University \& King Saud University. Higher Education Studies, Vol. 7, No. 3; 122-131.

Jais, A. (2018). Penerimaan dan penggunaan inovasi persekitaran pembelajaran maya (VLE) dalam kalangan guru. (Unpublished doctoral thesis). Universiti Kebangsaan Malaysia, Selangor, Malaysia.

Osman, B. H. A., \& Basar, M. N. (2016). Amalan Pengajaran Dan Pembelajaran Abad Ke- 21 Dalam Kalangan Pensyarah Institut Pendidikan Guru Kampus Ipoh. Jurnal Penyelidikan Dedikasi, 10(10,) 104-115.

Ball, D. L., Thames, M. H., \& Phelps, G. (2008). Content knowledge for teaching: What makes it special? Journal of Teacher Education, 59(5), 389-407.

Berry. J. (2012). The need to be innovative. AORN Journal, March, 95(3), 320-321.

Bruun, F. (2013). Elementary Teachers' Perspectives of Mathematics Problem Solving Strategies. The Mathematics Educator, 23(1), 45-59.

Carlgren. T. (2013). Communication, Critical Thinking, Problem Solving: A Suggested For all High

Fatemeh, M. J. (2015). Critical Reflection of an Iranian EFL Classroom: Effective Ploys in Narrative Paragraph Writing Development. Australian International Academic Centre, Australia. Vol. 6 No. 4; August 2015, 28-35.

Furgeson, P. (2013). Assessment, feedback and reporting. Teacher: Making a Difference, $2^{\text {nd }}$ Ed. Australia: John Wiley \& Son Australia.

Halim, L., \& Meerah, S. M. (2002). Science trainee teachers' pedagogical content knowledge and its influence on physics teaching. Research in Science and Technological Education, 20(2), 215-225. 
INTERNATIONAL JOURNAL OF ACADEMIC RESEARCH IN PROGRESSIVE EDUCATION AND

DEVELOPMENT

Vol. 8, No. 2, 2019, E-ISSN: 2226-6348 @ 2019 HRMARS

Farhana, L. M. I, Hayati M. Y. \& Md Nasirm, M. (2015). Menerokai kemahiran abad ke-21 kanakkanak dalam proses reka bentuk permainan digital. Journal of Science, Mathematics and Technology, 2(1), 82-96.

McMillan, J. \& Schumacher, S. (2014). Research in Education Evidence-Based Inquiry 7th. England. Pearson New International Edition.

Noziati, B. (2017). Model kepercayaan, sikap dan amalan pengajaran dalam kalangan guru permulaan matematik bagi sekolah rendah di Malaysia. Tesis Phd. Fakulti Pendidikan, Universiti Kebangsaan Malaysia. (Unpublished doctoral thesis). Universiti Kebangsaan Malaysia, Selangor, Malaysia.

Salmi, N. M. D. \& Mohd Isha, A. (2014). Tahap kemahiran komunikasi dalam kalangan pelajar sarjana muda pendidikan IPTA di utara Semenanjung Malaysia. Jurnal Pendidikan Bahasa Melayu. Vol. 4, Bil. 2 : 44-56

Ormod, J. E. (2014). Educational Psychology. Developing Learners. $8^{\text {th }}$ Ed. United States of America: Pearson Education.

Rosnah, I., Faizal, M. A. G. \& Saedah, S. (2013). Guru sekolah berprestasi tinggi. Jurnal Kurikulum \& Pengajaran Asia Pasifik, 1(2), 52.

Samsoo. M \& Abd Rahman, N. S. N. (2007). Factors Influencing Teacher' Perceptions on Teaching Thinking: A case Study in Kuala Lumpur, Malaysia The $4^{\text {th }}$ Postgraduate Research Colloquium IPRC Proceedings International Islamic University Malaysia.

Sanchez, A. B., Marcos, J. J. M., Gonzalez, M. \& Lin, H. G. (2012). In services teachers' attitudes towards the use of ICT in the classroom. Procedia Social and Behavioural Sciences, 46 : 1358-1364. DOI: 10.1016/j.sbspro.2012.05.302

Takahashi, A. (2016). Recent Trends in Japanese Mathematics Textbooks for Elementary Grades: Supporting Teachers to Teach Mathematics through Problem Solving. Universal Journal of Educational Research, 4(2), 313-319. https://doi.org/10.13189/ujer.2016.040201

Wilson-Ahlstrom, A., Yohalem, N., DuBois, D., \& Ji, P. (2014). From soft skills to hard data: measuring youth program outcomes. Washington, DC: The Forum for Youth Investment. 